Article

\title{
An In Silico Identification of Common Putative Vaccine Candidates against Treponema pallidum: A Reverse Vaccinology and Subtractive Genomics Based Approach
}

\author{
Arun Kumar Jaiswal ${ }^{1,2}$, Sandeep Tiwari ${ }^{1}$, Syed Babar Jamal ${ }^{1}$, Debmalya Barh ${ }^{1,3}$, \\ Vasco Azevedo ${ }^{1}$ and Siomar C. Soares ${ }^{2, *}$ \\ 1 Institute of Biological Sciences, Federal University of Minas Gerais, Belo Horizonte 31270-901, MG, Brazil; \\ arunjaiswal1411@gmail.com (A.K.J.); sandip_sbtbi@yahoo.com (S.T.); syedbabar.jamal@gmail.com (S.B.J.); \\ dr.barh@gmail.com (D.B.); vascoariston@gmail.com (V.A.) \\ 2 Department of Immunology, Microbiology and Parasitology, Institute of Biological Sciences and Natural \\ Sciences, Federal University of Triângulo Mineiro (UFTM), Uberaba 38025-180, MG, Brazil \\ 3 Centre for Genomics and Applied Gene Technology, Institute of Integrative Omics and Applied \\ Biotechnology (IIOAB), Nonakuri, Purba Medinipur, West Bengal 721137, India \\ * Correspondence: siomars@gmail.com
}

Academic Editor: Christopher Woelk

Received: 14 November 2016; Accepted: 27 January 2017; Published: 14 February 2017

\begin{abstract}
Sexually transmitted infections (STIs) are caused by a wide variety of bacteria, viruses, and parasites that are transmitted from one person to another primarily by vaginal, anal, or oral sexual contact. Syphilis is a serious disease caused by a sexually transmitted infection. Syphilis is caused by the bacterium Treponema pallidum subspecies pallidum. Treponema pallidum (T. pallidum) is a motile, gram-negative spirochete, which can be transmitted both sexually and from mother to child, and can invade virtually any organ or structure in the human body. The current worldwide prevalence of syphilis emphasizes the need for continued preventive measures and strategies. Unfortunately, effective measures are limited. In this study, we focus on the identification of vaccine targets and putative drugs against syphilis disease using reverse vaccinology and subtractive genomics. We compared 13 strains of T. pallidum using T. pallidum Nichols as the reference genome. Using an in silicoapproach, four pathogenic islands were detected in the genome of T. pallidum Nichols. We identified 15 putative antigenic proteins and sixdrug targets through reverse vaccinology and subtractive genomics, respectively, which can be used as candidate therapeutic targets in the future.
\end{abstract}

Keywords: sexually transmitted infections (STIs); drug target; vaccine target

\section{Introduction}

Sexually transmitted infections (STIs) are triggered by a number of bacteria, viruses, and parasites that are transferred mainly by vaginal, anal, or oral sexual contact between people. Different STIs can be existent or transmitted instantaneously, and such infections can trigger other STIs [1]. The World Health Organization (WHO) has reported more than 30 different bacteria, viruses, and parasites that are responsible for disease transmission through sexual contact.

Syphilis is among the most severe sexually transmitted infections (STIs) caused by the Treponema pallidum subspecies pallidum, a motile, gram-negative spirochete bacterium [2]. The annual estimated frequency of infectious syphilis is 36 million cases and over 11 million new infections; thus, it is an important public health burden globally [3]. Furthermore, the number of cases increased 10-fold 
in the last 15 years, with 4317 newly reported infections in 2014. This number is the highest it has been in the last 40 years and was mainly observed among men who have sex with men (MSM) [2].

If not properly treated, syphilis can cause long-term problems. It is important to screen women for syphilis during pregnancy to provide rapid treatment and to avoid congenital infections. Syphilis is a globally reemerging infection, as recently observed in the United States and Italy. Asian, African, and Latin American countries have high syphilis occurrences and are motivated to control prenatal care $[4,5]$. According to the Ministry of Health, in Brazil, 50,000 pregnant women are diagnosed with syphilis annually. The prevalence ranges from $1.1 \%$ to $11.5 \%$, depending on maternal schooling and prenatal care. As a result, almost 12,000 infants are born with congenital syphilis each year [4]. In Brazil, the regulation of syphilis is one of the goals of the Pact for Health project initiated by the World Health Organization (WHO) for the elimination of congenital syphilis [4].

Despite sevendecades of penicillin use for the treatment of syphilis infections, T. pallidum exhibits complete sensitivity to this antibiotic. An increase in treatment complexity has led to the use of azithromycin as an oral antibiotic. However, over the last few decades, resistance against macrolides has been reported in many countries and at present, macrolides are not recommended for the cure or prophylaxis of syphilis [6]. The recent global prevalence of syphilis elicits a need for sustained preventive measures and strategies. Unfortunately, effective measures are inadequate. Relevant application of chemicals, antibiotics, lotions, creams, and thorough washing with soap and water after sexual contact are ineffective. The development of an effective vaccination appears to be the only alternative for the control of syphilis in the future. In spite of intense research for developing proper syphilis treatments, restricted progress has been noticed [7]. There are recent cases of emergence reported in several countries including Norway [8], China [9], the United States, Western Europe [10], and Martinique [11]. Although in today's drug discovery process, high-throughput techniques and synthetic chemistry accelerate the process dramatically, it still takes 10-15 years to introduce a new drug to the market and therefore, a large investment is required [12].

The first step in the drug and vaccine discovery process is target identification. With the advent of new sequencing technologies and the deluge of genomic data, scientists are able to use computational methods to rapidly identify new targets, which are more time and cost effective than old approaches. Computational methods (i.e., subtractive genomics) are broadly used in this process. Recently, working with bacterial pathogens using an in silico approach, a large number of targets have been identified that are either resistant to drugs or for which no appropriate vaccine is available [13]. Reverse vaccinology is a conventional and popular approach in the post-genomic era for the prompt identification of novel vaccine targets [14,15]. Approaches, such as comparative and subtractive genomics and differential genome analyses [16], are being widely utilized for target identification in several human pathogens, including Mycobacterium tuberculosis [17], Helicobacter pylori [18], Burkholderia pseudomallei [19], Pseudomonas aeruginosa [20], Salmonella typhi [21], and Neisseria gonorrhoeae [22]. Generally, the principle behind these approaches is the identification of gene/protein targets that are essential for the survival of the pathogen but are not homologous to genes/proteins of the host [23]. Nevertheless, the identified targets may have a certain degree of homology with the host protein and are essential for the survival of the pathogen; hence, they can also be selected for structure-based selective inhibitor development as an additional molecular target. The differences in the active sites or other pockets with suitable druggability of the pathogenic protein could play an important role when compared to the host protein [24,25]. In this study, we mainly focus on the in silico identification of putative vaccine and drug targets against syphilis disease using reverse vaccinology and subtractive genomics. The goal was to identify plant-derived new lead antimicrobial compounds, and the proposed drug molecules show favorable interactions, lowered energy values, and high complementarity with the predicted targets. 


\section{Result and Discussion}

The total number of proteins described in each of the following sections and all the methodologies used in our work are described on the workflow in Figure 1.

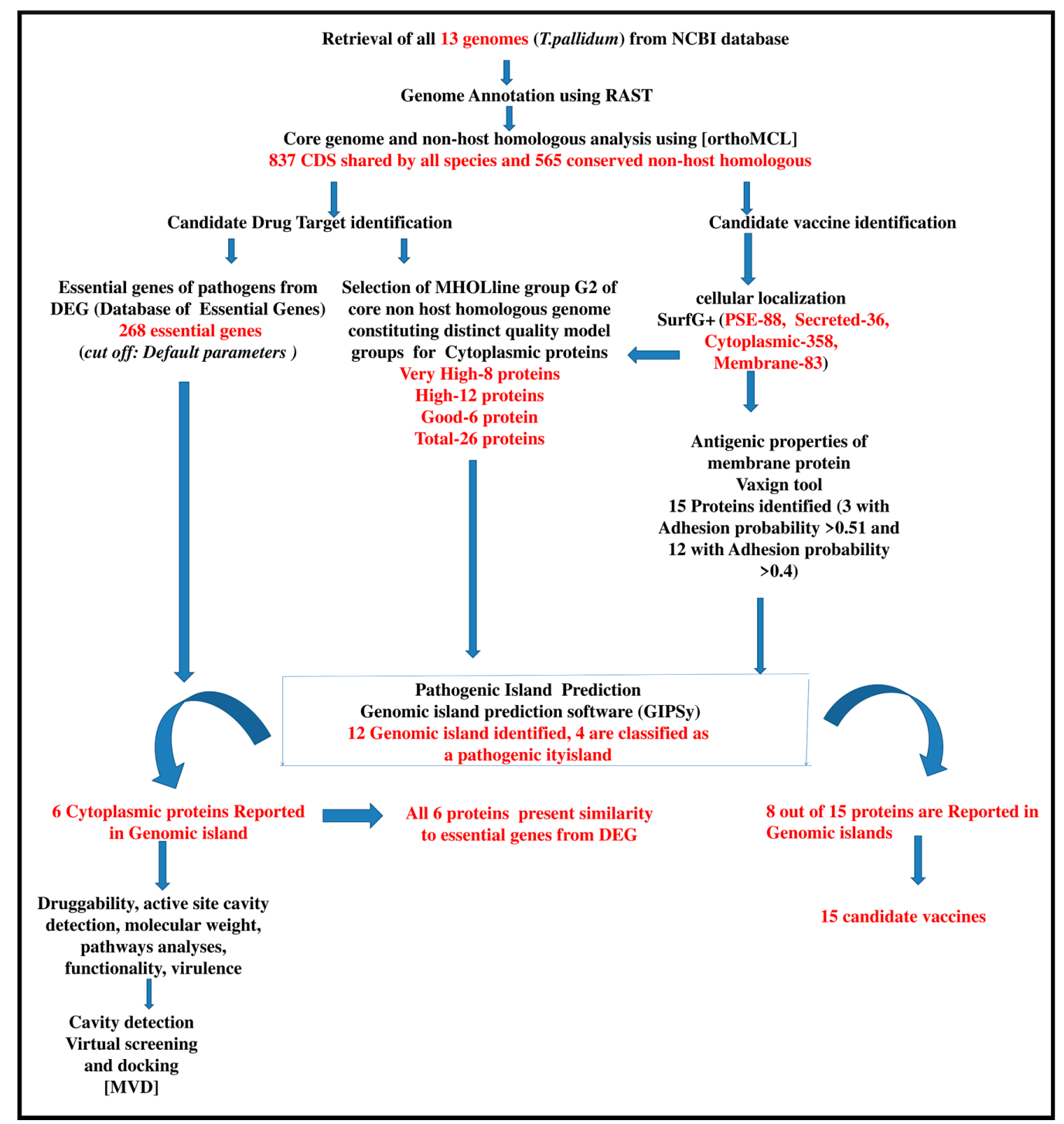

Figure 1. Complete workflow with the number of genes selected in each step and methodologies used. The sentences in black describe the analyses made and the software used in each step. The sentences in red represent the number of proteins selected in each step. CDS = coding DNA sequence; MVD = Molegro Virtual Docker.

\subsection{Identification of Intra-Species Conserved Non-Host Homologous Proteinsand Pathogenicity Islands}

We compared 13 Treponema pallidum strains (Table 1) using Treponema pallidum Nichols as the reference using the orthoMCL software [26]. Coding DNA sequences (CDSs) shared by all species were considered a part of the core genome. Considering the human genome as the host genome, a set of 565 conserved non-host homologous proteins were identified. The prediction of genomic islands (GIs) was subsequently performed. GIs are gene clusters, usually $>8 \mathrm{~kb}$ in size, likely acquired via horizontal gene transfers (HGT), and often playing a role in the environmental or host adaptation of bacteria. GIs significantly influence bacterial evolution and provide further insight in differentiating bacterial species and strains. For T. pallidum Nichols strains, 10 putative GIs were identified through 
the Genomic Island Prediction Software (GIPSy) [27], using Treponema denticola as a closely related, non-pathogenic organism. Of the $10 \mathrm{GIs}$, four are classified as pathogenicity islands (PAIs), i.e., they present high concentrations of virulence factors and are absent in the aforementioned closely related non-pathogenic organism (Figure 2).

Table 1. Genomic features of all T. pallidum (Tp) strains.

\begin{tabular}{ccccc}
\hline Strain & Size $\mathbf{( M b )}$ & GC\% & Gene & Protein \\
\hline Tp_Nichols & 1.13 & 52.80 & 1044 & 970 \\
Tp_Sea81-4 & 1.13 & 52.80 & 1032 & 931 \\
Tp_SS14 & 1.13 & 52.80 & 1042 & 971 \\
Tp_Chicago & 1.13 & 52.80 & 1030 & 969 \\
Tp_SamoaD & 1.13 & 52.80 & 1027 & 971 \\
Tp_CDC2 & 1.13 & 52.80 & 1030 & 973 \\
Tp_Gautheir & 1.13 & 52.80 & 1029 & 971 \\
Tp_DAL1 & 1.13 & 52.80 & 1030 & 969 \\
Tp_MexicoA & 1.14 & 52.80 & 1029 & 968 \\
Tp_Fribourg-Blanc & 1.14 & 52.80 & 1030 & 970 \\
Tp_SS14 (14.8.2015) & 1.13 & 52.80 & 1029 & 970 \\
Tp_BosniaA & 1.13 & 52.80 & 1027 & 970 \\
Tp_pallidum & 1.13 & 52.70 & 1033 & 964 \\
\hline
\end{tabular}

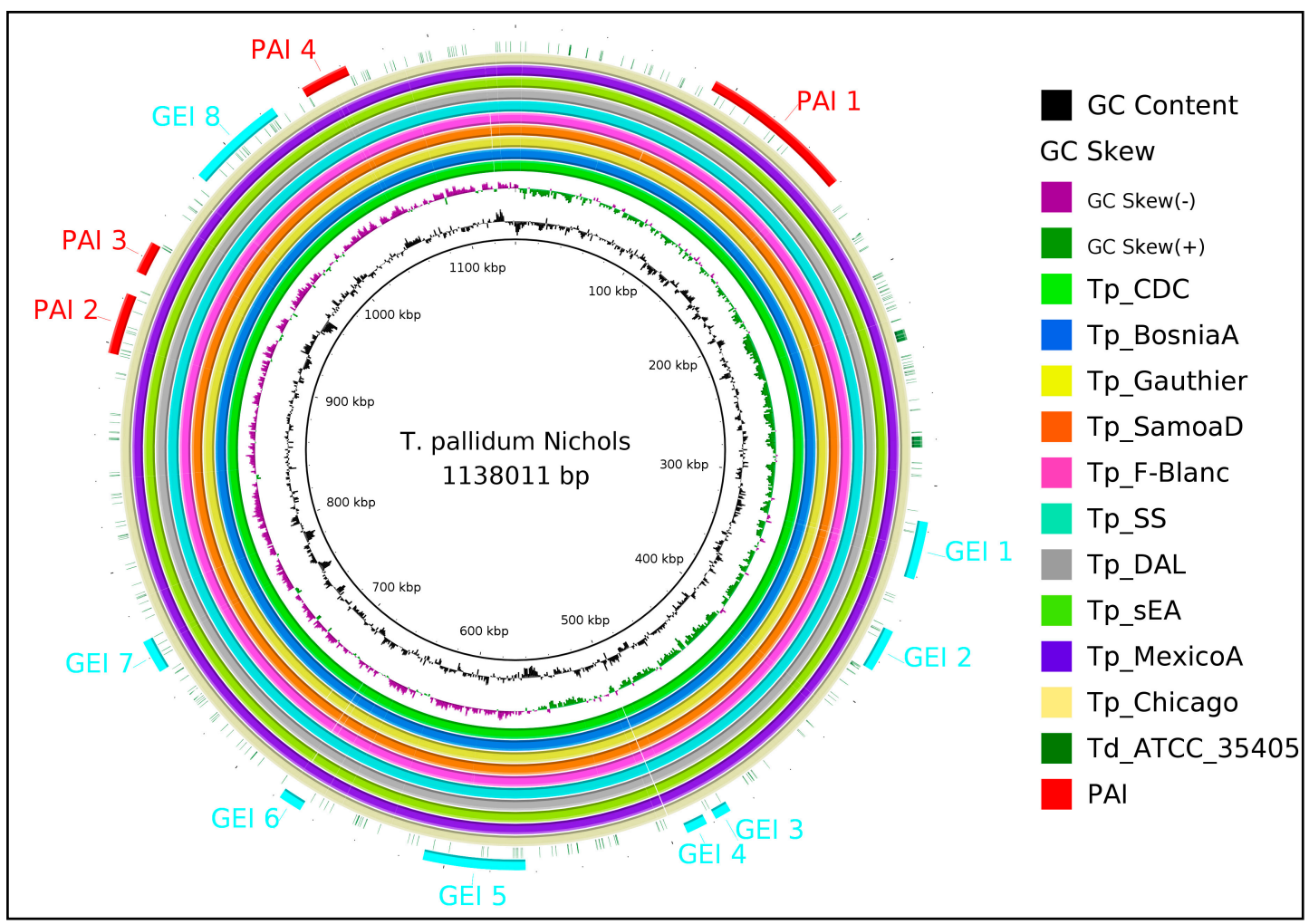

Figure 2. Genomic islands (GIs) of T. pallidum Nichols strains as predicted by the genomic island prediction software (GIPSy) using Treponema denticola as a closely related non-pathogenic organism. The outermost circle highlighted in red shows the four pathogenicity islands from 10 GIs. Guanine-Cytosine (GC) content is shown in black.

\subsection{Assessment of Essential Genes}

Essentiality analysis identifies significant genes required for pathogen survival such as adhesion, entry into the host, infection, and persistence in the host [13]. The conserved 565 non-hosts homologous 
proteins were subjected to the Database of Essential Genes (DEG) for the identification of essential proteins, through which a final set of 268 proteins was obtained (Table S1). Essential proteins are necessary for the survival of pathogen within the host. When these essential proteins are declared to be virulent, they can be of vital significance to unveil novel therapeutic targets. There is a probability of essential proteins to be conserved among various populations and species because of their vital roles in various pathways for pathogen survival [13,28]. Virulence is the characteristic of a pathogen responsible for causing severe human diseases. In the present study, these properties have been given high priority to identify potential vaccine candidates computationally. Although only 268 proteins were identified as essential by DEG, we considered all 565 proteins for our analyses.

\subsection{Prediction of Candidate Vaccine Target for T. pallidum}

The subcellular localization of conserved non-hosts homologous proteins of T. pallidum strains were predicted with the SurfG+ software [29]. We classified 207 gene products as putative surface-exposed (PSE) proteins, secreted proteins, or membrane proteins (Table 2). The proteins predicted by SurfG + were further analyzed with the software Vaxign [30] for antigenic properties with adhesion probabilities greater than 0.51 , resulting in the detection of three proteins in the T. pallidum strains Nichols (Table 3). We found that out of these three proteins, Tp_Nichols141 and Tp_Nichols797 were hypothetical proteins. Tp_Nichols141 belongs to the pathogenicity island 1 (Figure 2). When the adhesion probability threshold was $>0.4$, we also identified 12 more proteins that can also be considered potential vaccine candidates against T. pallidum.

Table 2. Subcellular location of Treponema pallidum (Tp) strain proteins.

\begin{tabular}{cc}
\hline Localization & Number of Proteins \\
\hline Cytoplasmic Protein & 358 \\
Membrane Protein & 83 \\
PSE ${ }^{\text {a }}$ & 88 \\
Secreted Protein $^{\text {a }}$ Putative Surface Exposed.
\end{tabular}

Previous studies have shown the importance of targeting proteins involved in the capability of T. pallidum to invade host tissues and to evade the functional immune response, contributing to its persistence during the "latency" stage. Most of the described gene targets code for proteins responsible for the attachment to extracellular matrix bridges (Tp0136, TP0155, Tp0483, and Tp0751), such as the low density integral Outer Membrane Proteins (OMPs) [6]. Briefly, in our predictions of good vaccine targets, we have identified Tp_Nichols350 and TpNichols852 with similarities to two previously described OMPs (TP0453 and Tp_0326), along with two additional OMP domain containing proteins: Tp_Nichols797 and Tp_Nichols141. Interestingly, both Tp_Nichols797 and Tp_Nichols141 presented adhesion probabilities higher than 0.5 and should be given priority in in vitro assays. 
Table 3. Putative antigenic proteins of Treponema pallidum (Tp) identified using Vaxign.

\begin{tabular}{|c|c|c|c|c|c|c|c|c|}
\hline Tp_Nichols & Protein ID & Gene Name & $\begin{array}{r}\text { Subcellular } \\
\text { Localization }\end{array}$ & $\begin{array}{l}\text { SignalP Result } \\
\text { (Cleavage Site) }\end{array}$ & $\begin{array}{c}\text { TMHMM } \\
\text { Result }\end{array}$ & InterProScan (Domain) & Gene Product & $\begin{array}{c}\text { Adhesion } \\
\text { Probability }\end{array}$ \\
\hline Tp_Nichols797 & WP_010882178.1 & - & SEC & $\begin{array}{c}\text { Yes } \\
\text { (between } 25 \text { and 26) }\end{array}$ & $\mathrm{TMH}=0$ & $\begin{array}{l}\text { Outer membrane protein/outer } \\
\text { membrane enzyme PagP, } \\
\text { beta-barrel-IPR011250 (65-219) }\end{array}$ & Hypothetical protein & 0.552 \\
\hline Tp_Nichols141 & WP_014342713.1 & - & PSE & No & $\mathrm{TMH}=1$ & $\begin{array}{l}\text { Outer membrane protein/outer } \\
\text { membrane enzyme PagP, } \\
\text { beta-barrel-IPR011250 (100-225) }\end{array}$ & Hypothetical protein & 0.525 \\
\hline Tp_Nichols466 & WP_010881878.1 & $n t p K$ & MEM & No & $\mathrm{TMH}=4$ & $\begin{array}{l}\text { V-ATPase proteolipid subunit } \\
\text { C-like domain_IPR002379 } \\
(76-138)\end{array}$ & $\begin{array}{l}\text { Two-sector ATPase, } \\
\text { V(0) subunit K }\end{array}$ & 0.590 \\
\hline Tp_Nichols930 & WP_010882306.1 & sly $D$ & PSE & No & $\mathrm{TMH}=1$ & $\begin{array}{l}\text { Peptidyl-prolyl cis-trans isomerase, } \\
\text { FKBP-type, } \\
\text { N-terminal-IPR000774 (66-143) }\end{array}$ & $\begin{array}{l}\text { FKBP-type peptidyl-prolyl } \\
\text { cis-trans isomerase SlyD }\end{array}$ & 0.488 \\
\hline Tp_Nichols471 & WP_010881883.1 & $n l p E$ & SEC & $\begin{array}{c}\text { Yes } \\
\text { (between } 23 \text { and 24) }\end{array}$ & $\mathrm{TMH}=0$ & No & $\begin{array}{l}\text { Copper resistance } \\
\text { lipoprotein NlpE }\end{array}$ & 0.475 \\
\hline Tp_Nichols650 & WP_010882040.1 & - & PSE & No & $\mathrm{TMH}=2$ & $\begin{array}{l}\text { Domain of unknown function } \\
\text { DUF2147-IPR019223 (71-193) }\end{array}$ & Hypothetical Protein & 0.474 \\
\hline Tp_Nichols1046 & WP_010882416.1 & ftr1 & MEM & No & $\mathrm{TMH}=6$ & No & $\begin{array}{c}\text { Conserved hypothetical integral } \\
\text { membrane protein }\end{array}$ & 0.44 \\
\hline Tp_Nichols52 & WP_010881498.1 & TPANIC_0600 & PSE & No & $\mathrm{TMH}=1$ & $\begin{array}{c}\text { Duplicated hybrid } \\
\text { motif-Ipr011055 (196-355) }\end{array}$ & Zinc metalloprotease & 0.428 \\
\hline Tp_Nichols610 & WP_010882004.1 & - & SEC & No & $\mathrm{TMH}=1$ & $\begin{array}{c}\text { Zinc finger, } \\
\text { CHCC-type-IPR019401 (8-34) }\end{array}$ & Hypothetical Protein & 0.425 \\
\hline Tp_Nichols323 & WP_010881746.1 & - & SEC & No & $\mathrm{TMH}=1$ & $\begin{array}{c}\text { Sporulation-related } \\
\text { domain-IPR007730 (172-252) }\end{array}$ & Hypothetical Protein & 0.41 \\
\hline Tp_Nichols852 & WP_010882234.1 & TP_0453 & SEC & $\begin{array}{c}\text { Yes } \\
\text { (between } 23 \text { and 24) } \\
\end{array}$ & $\mathrm{TMH}=0$ & No & Outer membrane protein TP0453 & 0.408 \\
\hline Tp_Nichols350 & WP_014342788.1 & $\operatorname{tp} 92$ & SEC & $\begin{array}{c}\text { Yes } \\
\text { (between } 37 \text { and 38) }\end{array}$ & $\mathrm{TMH}=1$ & $\begin{array}{l}\text { Bacterial surface antigen } \\
\text { (D15)-IPR000184 (478-849) }\end{array}$ & $\begin{array}{c}\text { Putative outer membrane } \\
\text { protein assembly factor TP_0326 }\end{array}$ & 0.405 \\
\hline Tp_Nichols98 & WP_010881537.1 & - & PSE & No & $\mathrm{TMH}=0$ & No & Hypothetical Protein & 0.401 \\
\hline Tp_Nichols347 & WP_010881771.1 & TP_0323 & MEM & No & & No & $\begin{array}{l}\text { Ribose/galactose } \mathrm{ABC} \\
\text { transporter, permease } \\
\text { protein (RbsC-2) }\end{array}$ & 0.401 \\
\hline Tp_Nichols362 & WP_010881783.1 & TPANIC_0335 & MEM & No & $\mathrm{TMH}=2$ & No & Putative membrane protein & 0.401 \\
\hline
\end{tabular}

SEC = secreted; PSE = Putative surface exposed; MEM = Membrane; TMH = Transmembrane Helix, TMHMM = Transmembrane Helix prediction server, based on a hidden Markov model. 


\subsection{High Throughput Structural Modeling}

The main focus of this study was to find candidate vaccine targets. However, according to Caroline et al., 2014 [6], the difficulty in curing syphilis is due to the vilification of many antibiotics for treatment or prophylaxis. Our contributionsincludetheprediction of some novel drug targets against Treponema pallidum. For this, the identified 565 conserved non-host homologous Treponema pallidum proteins were submitted to MHOLline [31] an online web tool, to predict the modelome. MHOLline utilizes multi-fasta files of amino acids as an input data and then uses HMMTOP, BLAST, BATS, MODELLER, and PROCHECK programs for the detailed analyses. The program HMMTOP detects transmembrane regions. The BLAST algorithm is used to identify the template structure by performing a random search against the Protein Data Bank. BATS (Blast Automatic Targeting for Structures) carries out the refinement in the template search and it is a key step for the model construction. BATS refinement identifies sequences that make the modeling possible by selecting a template from a BLAST output file using their BATS scores, expectation values, identity, and sequence similarity as criteria, as well as considering the number of gaps and the alignment coverage. BATS selects the best template for 3D model generation and performs automated alignment using the MODELLER program. Furthermore, it gathers all the BLAST output files into four distinctive groups (i.e., G0, G1, G2, and G3) according to the following criteria: $\mathrm{G} 0=$ unaligned sequence; $\mathrm{G} 1=\mathrm{E}$-value $>10 \times 10^{-5}$ or identity $<15 \%$; G2 $=$ E-value $\leq 10 \times 10^{-5}$ and identity $\geq 25 \%$ AND LVI $\leq 0.7 ;$ G3 $=$ E-value $\leq 10 \times 10^{-5}$ and identity $\leq 15 \%$ and $<25 \%$ OR LVI (Length Variation Index) $>0.7$. Only the first three distinct quality G2 model groups were taken into consideration in this study; these were: 1—very high quality model sequences (identity $\geq 75 \%$ ) (LVI $\leq 0.1)$, 2-high quality model sequences (identity $\geq 50 \%$ ) and $<75 \%)(\mathrm{LVI} \leq 0.1)$, and 3-good quality model sequences (identity $\geq 50 \%)(\mathrm{LVI}>0.1$ and $\leq 0.3)$ [31]). Therefore, all the considered protein 3D models were constructed from sequences for which their template is available with identity $\geq 50 \%$. We found 26 proteins ( 8 very high, 12 high, and 6 good) in the first 3 distinct quality $\mathrm{G} 2$ model groups.

The membrane and cell wall associated proteins are, theoretically, more exposed as targets than the cytoplasmic drug targets. However, membrane proteins are difficulty to purify and assay [32]. Cytoplasmic membrane proteins are also very important for the physiology of bacteria, as they are involved in many important metabolic functions. Therefore, the membrane, putative surface exposed, and secreted proteins are better applicable as targets for reverse vaccinology, whereas the pivotal role of cytoplasmic proteins in maintenance of cell viability makes them more favorable as drug targets [33]. Out of the 26 proteins, only cytoplasmic proteins that were present in any GIs were selected as candidate drug targets. Six proteins that were also present in the 268 proteins were identified as essential in the DEG analyses and were considered for the target prioritization and docking studies (Table 4).

The outer membrane may pose a barrier for drugs to gain access to cytoplasmic targets. However, small molecules are able to gain access to the periplasm through porins and reach the cytoplasm. In previous studies, it was shown that one of the pore forming OMPs, OmpF, has an exclusion limit of 600 Daltons, for example, which is used by ions, amino acids, and small sugars as a means to reach the periplasm [34]. The molecular weight of the compounds used here varies from $\sim 275.1 \mathrm{~g} / \mathrm{mol}$ (liriodenine) to $488.7 \mathrm{~g} / \mathrm{mol}$ (jacarandic acid) and they may also be able to use porins to gain access to the periplasm. Alternatively, the use of nanoparticles as delivery systems or a combined treatment, such as with polymyxins and derivatives that increase the permeability of the outer membrane, may also help in overcoming the outer membrane barrier [35]. 
Table 4. Drug target prioritization parameters and functional annotation of the six non-homologous putative targets.

\begin{tabular}{|c|c|c|c|c|c|c|c|}
\hline $\begin{array}{l}\text { Locus Tag, Gene, } \\
\text { and Protein ID }\end{array}$ & Official Full Name & Mol. Wt (KDa) a & Functions ${ }^{b}$ & $\begin{array}{c}\text { Cellular } \\
\text { Component }\end{array}$ & Pathways ${ }^{d}$ & Virulence $^{\mathrm{e}}$ & DEG Analyses \\
\hline $\begin{array}{l}\text { Tp_Nichols130, uvrB, } \\
\text { WP_010881565.1 }\end{array}$ & $\begin{array}{l}\text { UvrABC system } \\
\text { protein B }\end{array}$ & 76.19 & $\begin{array}{l}\text { MF: ATP (Adenosine triphosphate) } \\
\text { binding, DNA binding, excinuclease } \\
\text { ABC activity, helicase activity. BP: } \\
\text { nucleotide-excision repair, SOS response. }\end{array}$ & Cytoplasm & Unknown & Yes & Essential gene \\
\hline $\begin{array}{l}\text { Tp_Nichols593, Pfp, } \\
\text { WP_010881989.1 }\end{array}$ & $\begin{array}{l}\text { Pyrophosphate-fructose } \\
\text { 6-phosphate } \\
\text { 1-phosphotransferase }\end{array}$ & 62.43 & - & Cytoplasm & Glycolysis & Yes & Essential gene \\
\hline $\begin{array}{l}\text { Tp_Nichols609, asnA, } \\
\text { WP_010882003.1 }\end{array}$ & $\begin{array}{l}\text { Aspartate-ammonia } \\
\text { ligase }\end{array}$ & 36.86 & $\begin{array}{l}\text { MF: Aminoacyl-tRNA ligase activity, } \\
\text { aspartate-ammonia ligase activity, ATP } \\
\text { binding.BP: L-asparagine biosynthetic } \\
\text { process, tRNA aminoacylation for } \\
\text { protein translation. }\end{array}$ & Cytoplasm & L-asparaginebiosynthesis & Yes & Essential gene \\
\hline $\begin{array}{l}\text { Tp_Nichols754, recA, } \\
\text { WP_010882137.1 }\end{array}$ & Protein RecA & 45.33 & $\begin{array}{l}\text { MF: ATP binding, damaged DNA binding, } \\
\text { DNA-dependent ATPase activity, single } \\
\text { stranded DNA binding.BP: DNA } \\
\text { recombination, DNA repair, SOS response. }\end{array}$ & Cytoplasm & Unknown & Yes & Essential gene \\
\hline $\begin{array}{l}\text { Tp_Nichols990, Ndh, } \\
\text { WP_010882364.1 }\end{array}$ & $\begin{array}{l}\text { NADH (Nicotinamide } \\
\text { adenine dinucleotide) } \\
\text { dehydrogenase }\end{array}$ & 48.64 & $\begin{array}{l}\text { MF: flavin adenine dinucleotide binding, } \\
\text { NADH dehydrogenase activity.BP: cell } \\
\text { redox homeostasis. }\end{array}$ & Cytoplasmic & Unknown & Yes & Essential gene \\
\hline $\begin{array}{l}\text { Tp_Nichols1011, Dxs, } \\
\text { WP_010882382.1 }\end{array}$ & $\begin{array}{l}\text { 1-deoxy-D-xylulose- } \\
5 \text {-phosphate synthase }\end{array}$ & 129.82 & $\begin{array}{l}\text { MF: 1-deoxy-D-xylulose-5-phosphate } \\
\text { synthase activity, magnesium ion binding, } \\
\text { thiamine pyrophosphate binding.BP: } \\
\text { 1-deoxy-D-xylulose-5-phosphate } \\
\text { biosynthetic process, terpenoid } \\
\text { biosynthesis process, Thiamine } \\
\text { biosynthesis process. }\end{array}$ & Cytoplasmic & $\begin{array}{l}\text { 1-deoxy-D-xylulose } \\
\text { 5-phosphate } \\
\text { biosynthesis }\end{array}$ & Yes & Essential gene \\
\hline
\end{tabular}




\subsection{Analyses of Non-Host Homologous Targets and Molecular Docking}

In molecular docking, lower energy scores represent better protein-ligand bindings compared to higher energy values [37]. We considered the lower MolDock score and the interaction with the residues that were involved in the active site of the target for the prediction of therapeutic candidates. For each target protein (uvrB, pfp, asnA, recA, ndh, and dxs), a library of 28 natural compounds were docked to examine each molecule one-by-one for the selection of the final set of promising molecules that showed favorable interactions with the active site residues of targets. The biological importance for each target is described here (Table 4) along with an analysis of the predicted protein-ligand interaction(s). The name of the molecules, MolDock scores for the selected ligands, and the number of predicted hydrogen bonds with the active residues involved in these interactions are shown below for each target protein (Table 5). The predicted configurations of one of the best-docked molecules are also shown for each pathogen target in Figure 3A-F.

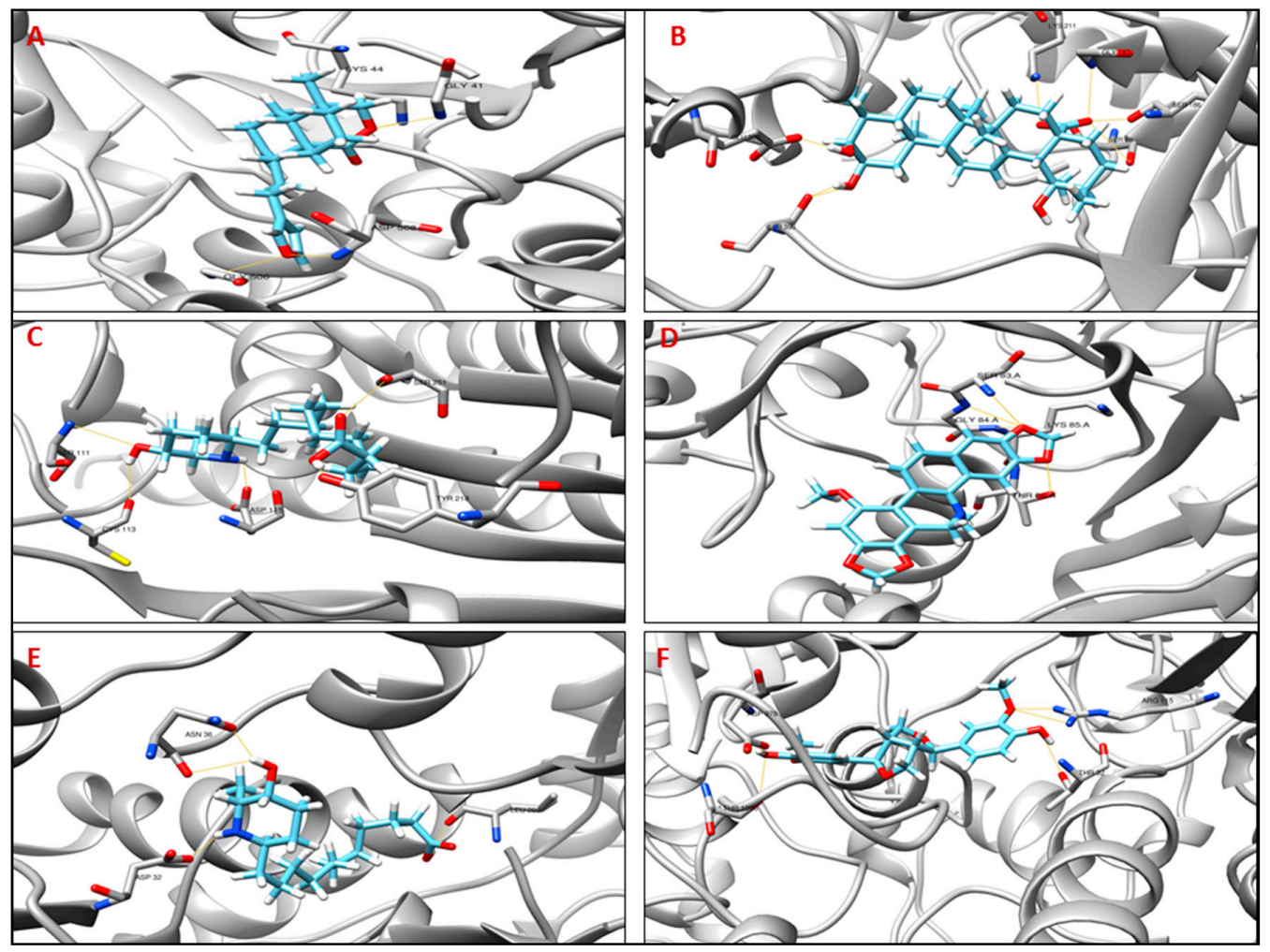

Figure 3. 3D graphic representation of the docking analyses for the most druggable protein cavity of drug target. (A) Tp_Nichols130 (uvrB, Uvr ABC system protein B) with potamogetonin (CID 5742898); (B) Tp_Nichols593 (pfp, pyrophosphate-fructose 6-phosphate 1-phosphotransferase) with jacarandic acid (CID 73645); (C) Tp_Nichols609 (asnA, aspartate-ammonia ligase) with leptophyllin B (CID 10447482); (D) Tp_Nichols754 (recA, RecA protein) with dihydrochelirubine (CID 440589); (E) Tp_Nichols9904 (ndh, NADH dehydrogenase) with leptophyllin B (CID 10447482); (F) Tp_Nichols1011 (dxs 1-deoxy-D-xylulose-5-phosphate synthase) with pinoresinol (CID 234817).

Based on a structural comparison with a crystallographic structure of the uvrB template (2d7d, uvrB from Bacillus subtilis), the active site residues involved in H-bond interactions with the crystallographic ligand adenosine-5'-diphosphate are Phe10, Gln11, Gln16, Gly41, Gly43, and Arg541. One of these residues, Gly41, was predicted to make hydrogen bonds to the ligand potamogetonin (CID 5742898) with a MolDock score of -97.81. Similarly, for the target pfp template (2F48, Borrelia burgdorferi), the active site residues involving in H-bond interactions are Lys211, Pro210, Asp214, Gly90, Tyr434, Arg154, Met259, Arg261, and Glu320. The residue Lys211 interacts with 
jacarandic acid (CID 73645) and pinoresinol (CID 234817) with MolDock scores of -62.15 and -112.67 , respectively. The compound leptophyllin B (CID 10447482) interacts with the identified active site residues Ser111, Cys113, Asp115, Tyr218, and Ser251of asnA (PDB ID: 12AS from Escherichia coli) and Leu298, Asp32, and Asn36 of ndh (PDB Template ID: 2BC0 from Streptococcus pyogenes).

Interestingly, the drug molecule pinoresinol (CID234817) was predicted to show good results against four of our targets uvrB, pfp, asnA, and dxs. Pinoresinol is a lignan, biphenolic compound found in Araucaria araucana and Sambucus williamsii. It possesses bactericidal and fungicidal activities and therapeutic potential as an antifungal agent for the treatment of fungal infectious diseases in humans $[38,39]$. Thus, the identification of pinoresinol in our in silico study strengthens our protocol and can be potentially used as a new drug for the treatment of syphilis.

Table 5. The MolDock scores of natural compounds and predicted hydrogen bonds for the selected best-ranked molecules against each drug target.

\begin{tabular}{|c|c|c|c|}
\hline Compounds Name & MolDock Score & Number of H-Bond & Residues Interacting \\
\hline \multicolumn{4}{|c|}{ Tp_Nichols130 (UvrB, Uvr ABC System Protein B) } \\
\hline $\begin{array}{l}\text { Diospyrin (CID 308140) } \\
\text { MW: } \sim 374.3 \mathrm{~g} / \mathrm{mol}\end{array}$ & -119.83 & 4 & Gly506, Asp508 \\
\hline $\begin{array}{l}\text { Pinoresinol (CID 234817) } \\
\text { MW: } \sim 358.4 \mathrm{~g} / \mathrm{mol}\end{array}$ & -114.82 & 2 & His64, Asp508 \\
\hline $\begin{array}{l}\text { Potamogetonin (CID 5742898) } \\
\text { MW: } ~ 314.4 \mathrm{~g} / \mathrm{mol}\end{array}$ & -97.81 & 4 & Gly41, Lys44, Gly506, Asp508 \\
\hline \multicolumn{4}{|c|}{ Tp_Nichols593 (pfp, Pyrophosphate-fructose 6-phosphate 1-phosphotransferase) } \\
\hline $\begin{array}{l}\text { Pinoresinol (CID 234817) } \\
\text { MW: } 358.4 \mathrm{~g} / \mathrm{mol}\end{array}$ & -112.67 & 5 & Ser88, Lys211, Gly260, Glu320 \\
\hline $\begin{array}{c}\text { Jacarandic acid (CID 73645) } \\
\text { MW: } \sim 488.7 \mathrm{~g} / \mathrm{mol}\end{array}$ & -62.15 & 7 & Ser88, Ser186, Gly183, Lys211, Glu320, Ser396 \\
\hline $\begin{array}{l}\text { Texalin (CID 473253) } \\
\text { MW: } \sim 266.3 \mathrm{~g} / \mathrm{mol}\end{array}$ & -91.57 & 4 & Gly90, Thr212, Ser186, Ile213 \\
\hline \multicolumn{4}{|c|}{ Tp_Nichols609 (asnA, Aspartate-ammonia ligase) } \\
\hline $\begin{array}{c}\text { Leptophyllin B (CID 10447482) } \\
\text { MW: 299.4 g/mol }\end{array}$ & -141.21 & 5 & Ser111, Cys113, Asp115, Tyr218, Ser251 \\
\hline $\begin{array}{c}\text { Pinoresinol (CID 234817) } \\
\text { MW: } ~ 358.4 \mathrm{~g} / \mathrm{mol}\end{array}$ & -132.814 & 5 & Ser49, Lys77, Ser251, Arg255 \\
\hline $\begin{array}{l}\text { Liriodenine (CID 10144) } \\
\text { MW: } 275.1 \mathrm{~g} / \mathrm{mol}\end{array}$ & -95.65 & 2 & Lys77, Arg255 \\
\hline \multicolumn{4}{|c|}{ Tp_Nichols754 (recA, Protein RecA) } \\
\hline $\begin{array}{l}\text { Dihydrochelirubine (CID 440589) } \\
\text { MW: } \sim 363.4 \mathrm{~g} / \mathrm{mol}\end{array}$ & -138.94 & 4 & Gly84, Lys85, Ser83, Thr86 \\
\hline $\begin{array}{l}\text { Piperine (CID 638024) } \\
\text { MW: } \sim 285.3 \mathrm{~g} / \mathrm{mol}\end{array}$ & -17.14 & 5 & Ser83, Gly84, Lys84, Gln207, Gly279 \\
\hline $\begin{array}{l}\text { Rhein (CID 10168) } \\
\text { MW: 284.2 g/mol }\end{array}$ & -96.11 & 7 & Ser83, Gly84, Thr86, Tyr116, Asn254, Gly279 \\
\hline \multicolumn{4}{|c|}{ Tp_Nichols990 (ndh, NADH dehydrogenase) } \\
\hline $\begin{array}{l}\text { Leptophyllin B (CID 10447482) } \\
\text { MW: 299.4 g/mol }\end{array}$ & -122.62 & 4 & Leu298, Asp32, Asn36 \\
\hline $\begin{array}{l}\text { Dicentrinone (CID 177744) } \\
\text { MW: } 335.3 \mathrm{~g} / \mathrm{mol}\end{array}$ & -111.09 & 4 & Arg33, Ala11 \\
\hline $\begin{array}{l}\text { Isosakuranetin (CID 160481) } \\
\text { MW: } \sim 286.3 \mathrm{~g} / \mathrm{mol}\end{array}$ & -109.35 & 3 & Arg33, Ala11, Cyc42 \\
\hline \multicolumn{4}{|c|}{ Tp_Nichols1011 (dxs, 1-deoxy-D-xylulose-5-phosphate synthase) } \\
\hline $\begin{array}{l}\text { Pinoresinol (CID 234817) } \\
\text { MW: } 358.4 \mathrm{~g} / \mathrm{mol}\end{array}$ & -146.18 & 5 & Asp978, Thr1006, Thr32, Arg115 \\
\hline $\begin{array}{l}\text { Piperine (CID 638024) } \\
\text { MW: 285.3 g/mol }\end{array}$ & -131.40 & 3 & Thr32, Arg115, Trp980 \\
\hline $\begin{array}{l}\text { Berberine (CID 2353) } \\
\text { MW: } \sim 336.4 \mathrm{~g} / \mathrm{mol}\end{array}$ & -115.94 & 3 & Thr32, Gly979, Asn1011 \\
\hline
\end{tabular}




\section{Materials and Methods}

\subsection{Selection of Data}

The genome sequences of all 13 strains of $T$. pallidum were retrieved from the NCBI (National Center for Biotechnology Information) server [40]. For homogeneity in the functional annotation, all genomes were annotated using the RAST server (RapidAnnotationsusing SubsystemsTechnology) [41]. Furthermore, these annotated genome sequences were used for analysis.

\subsection{Identification of Intra-Species Conserved Non-Host Homologous Proteins}

In comparative genomics, the orthologous genes are clustered to obtain a framework to integrate information from multiple genomes, highlighting the conservation and divergence of gene families and biological processes. For pathogens, clustering orthologs can facilitate drug and/or vaccine targets identification. We compared 13 strains of Treponema pallidum using Treponema pallidum Nichols as the reference genome, using orthoMCL software [26] with an E-value of $1 \times 10^{-50}$. CDSs shared by all strains were considered a part of the core genome. The possible candidates for drugs and/or vaccines should be non-homologues to human proteins; thus, autoimmunity is avoided, and an accurate immune response is elicited against the targeted pathogen. Accordingly, these core genes were subjected to orthoMCL software $\left(\right.$ E-value $\left.=1 \times 10^{-50}\right)$ against the human genome for the identification of non-host homolog targets.

\subsection{Identification of Pathogenicity Islands}

Knowledge about pathogenicity islands, the virulence factors they encode, their mobility, and their structure is not only helpful in understanding the bacterial evolution and their interactions with eukaryotic host cells, but may also facilitate in providing delivery systems for vaccination and tools for the development of new approaches for treating bacterial infections [28]. The identification of pathogenicity islands in the genome of T. pallidum Nichols was performed with GIPSy (Genomic Island Prediction Software) [27] through the detection of regions presenting: deviations in genomic signature (i.e., anomalous $\mathrm{G}+\mathrm{C}$ and/or codon usage deviation); presence of transposase, virulence or flanking tRNA genes; and absence in the non-pathogenic organism Treponema denticola.

\subsection{Assessment of Essential Genes}

A subtractive genomics approach was followed to identify conserved targets that were essential to the bacteria [13]. The set of core conserved proteins of T. pallidum Nichols was subjected to the Database of Essential Genes (DEG) [42] for homology analyses. The DEG contains experimentally validated data from bacteria, archaea, and eukaryotes that are comprised of currently reported essential genomic elements including protein-coding genes that are indispensable to support cellular life. The cut-off values used for BLASTp were: E-value $=0.0001$, bit score $=100$, and identity $=25 \%[15,18,30]$.

\subsection{Reverse Vaccinology Approach for Prediction of Putative T. pallidum Vaccine Targets}

For potential vaccine targets, subcellular localization and the secretion of pathogenic proteins are important factors for consideration, where secreted and membrane proteins are the first to be in contact with the host, eliciting an immune response. Therefore, the prediction of the exoproteome or secretome, composed of the proteins localized in the extracellular matrix or outer membrane of the organism, is highly valuable for reverse vaccinology strategies. In combination with subtractive proteomics, reverse vaccinology can provide a more reliable output compared to screening of the whole data set without considering prioritizing parameters [13]. The non-host homologous conserved proteome of T. pallidum Nichols was screened using SurfG+ software [29] to identify secreted proteins, membrane proteins, and putative surface exposed proteins. We searched for cleavage sites and transmembrane helices in all 15 proteins using SignalP [43] and TMHMM (Transmembrane Helix prediction server, based on 
a hidden Markov model) [44], respectively, and we also predicted the presence of functional domains for all the 15 proteins with InterProScan, which uses several databases for domain prediction [45]. The dataset was screened by Vaxign [30] by searching for proteins with the following features: major histocompatibility complex (MHC I) and (MHC II) binding properties, an adhesion probability greater than 0.51 , and no similarity to host proteins.

\subsection{High Throughput Structural Modeling}

MHOLline [31] was used to predict the modelome (complete set of protein 3D models for the whole conserved core non-host homologous proteome). MHOLline utilizes multi-fasta files of amino acids as input data and then uses HMMTOP, BLAST, BATS, MODELLER, and PROCHECK programs for the detailed analyses. The program HMMTOP detects transmembrane regions [46]. The BLAST algorithm is used to identify template structure by performing random searches against the Protein Data Bank [47]. BATS (Blast Automatic Targeting for Structures) performs the refinement in the template search; its use represents a key step for the model construction. BATS refinement identifies sequences that make the modeling possible by selecting templates from the BLAST output file using their BATS scores, expectation values, identity, and sequence similarity as criteria as well as considering the number of gaps and the alignment coverage. BATS selects the best template for 3D model generation and performs automated alignment used by the MODELLER program. The adopted methodology was revised accordingly from the original work by Hassan et al. [46].

\subsection{Ligand Libraries and Docking Analyses}

The ligand libraries of 28 natural compounds presented by Tiwari et al., 2014 [48] were used for the docking analysis. The 3D structures of all target proteins were carefully examined for structural errors (wrong bonds, missing atoms, and protonation states) in the MVD (Molegro Virtual Docker) [37]. The active side residues of the target proteins were identified by comparing its $3 \mathrm{D}$ structure to the respective templates. Furthermore, taking identified cavities from a template used in a grid for molecular docking. The program includes three search algorithms for molecular docking analyses, namely MolDock Optimizer [37], MolDock Simplex Evolution (SE), and Iterated Simplex (IS). We employed the MolDock Optimizer search algorithm, which is based on a differential evolutionary algorithm, using the default parameters, that are (a) population size $=50$; (b) scaling factor $=0.5$; and (c) crossover rate $=0.9$. The 3D poses of docked molecules were analyzed in Chimera [49]. Molecular function (MF) and biological process (BP) for each target protein were determined using UniProt [41]. The biochemical pathway of these proteins were checked using KEGG (Kyoto Encyclopedia of Genes and Genomes) [50], SurfG+ software [29], and virulence using GIPSy [31]. The final list of targets was based on 12 criteria, as described earlier in [13,46].

\section{Conclusions}

Here, the genomic information was used with the aim of determining the conserved proteome of 13 strains of Treponema pallidum in a search for regions of genome plasticity. Moreover, we used reverse vaccinology and subtractive genomics to predict new antigenic/drug targets, which can be used in the development of new vaccines and drugs for Treponema pallidum. After a detailed in silico analysis between host and pathogen proteins, we suggest that the identified non-host homologous proteins could be considered for prophylaxis of syphilis due to further experimental validations.

Supplementary Materials: Supplementary materials can be found at www.mdpi.com/1422-0067/18/2/402/s1.

Acknowledgments: We acknowledge the support of all team members and financing agencies. Arun Kumar Jaiswal was supported by the CAPES (Coordenação de Aperfeiçoamento de Pessoal de Nível Superior, Brasil) fellowship for doctoral studies. Sandeep Tiwari, Syed Babar Jamal acknowledges the "TWAS-CNPq Postgraduate Fellowship Programme" for granting a fellowship for doctoral studies. Debmalya Barh acknowledges the "TWAS-CNPq Postdoctoral Fellowship Programme" for granting a fellowship for postdoctoral studies. 
The authors also thank the funding agency FAPEMIG (Fundação de Amparo à Pesquisa de Minas Gerais) for financial support.

Author Contributions: Arun Kumar Jaiswal, Sandeep Tiwari, and Siomar C. Soares planned the entire work; Arun Kumar Jaiswal, Sandeep Tiwari, Syed Babar Jamal, and Siomar C. Soares analyzed the data; Arun Kumar Jaiswal, Sandeep Tiwari, Syed Babar Jamal, and Siomar C. Soares drafted the manuscript; Siomar C. Soares, Vasco Azevedo, Sandeep Tiwari, Debmalya Barh, and Arun Kumar Jaiswal reviewed and analyzed the manuscript.

Conflicts of Interest: The authors declare that they have no conflict of interest.

\section{References}

1. Wagenlehner, F.M.; Brockmeyer, N.H.; Discher, T.; Friese, K.; Wichelhaus, T.A. The presentation, diagnosis, and treatment of sexually transmitted infections. Dtsch. Arztebl. Int. 2016, 113, 11-22. [PubMed]

2. Nyatsanza, F.; Tipple, C. Syphilis: Presentations in general medicine. Clin. Med. 2016, 16, 184-188. [CrossRef] [PubMed]

3. Newman, L.; Rowley, J.; Vander Hoorn, S.; Wijesooriya, N.S.; Unemo, M.; Low, N.; Stevens, G.; Gottlieb, S.; Kiarie, J.; Temmerman, M. Global estimates of the prevalence and incidence of four curable sexually transmitted infections in 2012 based on systematic review and global reporting. PLoS ONE 2015, 10, e0143304. [CrossRef] [PubMed]

4. Lafeta, K.R.; Martelli Junior, H.; Silveira, M.F.; Paranaiba, L.M. Maternal and congenital syphilis, underreported and difficult to control. Rev. Bras. Epidemiol. 2016, 19, 63-74. [PubMed]

5. Deperthes, B.D.; Meheus, A.; O'Reilly, K.; Broutet, N. Maternal and congenital syphilis programmes: Case studies in Bolivia, Kenya and South Africa. Bull World Health Organ 2004, 82, 410-416. [PubMed]

6. Cameron, C.E.; Lukehart, S.A. Current status of syphilis vaccine development: Need, challenges, prospects. Vaccine 2014, 32, 1602-1609. [CrossRef] [PubMed]

7. Radolf, J.D. Treponema. In Medical Microbiology, 4th ed.; Baron, S., Ed.; University of Texas Medical Branch at Galveston: Galveston, TX, USA, 1996.

8. Jakopanec, I.; Grjibovski, A.M.; Nilsen, O.; Aavitsland, P. Syphilis epidemiology in Norway, 1992-2008: Resurgence among men who have sex with men. BMC Infect. Dis. 2010, 10. [CrossRef] [PubMed]

9. Tucker, J.D.; Cohen, M.S. China's syphilis epidemic: Epidemiology, proximate determinants of spread, and control responses. Curr. Opin. Infect. Dis. 2011, 24, 50-55. [CrossRef] [PubMed]

10. Abara, W.E.; Hess, K.L.; Neblett Fanfair, R.; Bernstein, K.T.; Paz-Bailey, G. Syphilis trends among men who have sex with men in the United States and Western Europe: A systematic review of trend studies published between 2004 and 2015. PLoS ONE 2016, 11, e0159309. [CrossRef] [PubMed]

11. Cabie, A.; Rollin, B.; Pierre-Francois, S.; Abel, S.; Desbois, N.; Richard, P.; Hochedez, P.; Theodose, R.; Quist, D.; Helenon, R.; et al. Reemergence of syphilis in Martinique, 2001-2008. Emerg. Infect. Dis. 2010, 16, 106-109. [CrossRef] [PubMed]

12. Plotkin, S.A. Why certain vaccines have been delayed or not developed at all. Health Aff. 2005, 24, 631-634. [CrossRef] [PubMed]

13. Barh, D.; Tiwari, S.; Jain, N.; Ali, A.; Santos, A.R.; Misra, A.N.; Azevedo, V.; Kumar, A. In silico subtractive genomics for target identification in human bacterial pathogens. Drug Dev. Res. 2011, 72, 162-177. [CrossRef]

14. Barh, D.; Gupta, K.; Jain, N.; Khatri, G.; Leon-Sicairos, N.; Canizalez-Roman, A.; Tiwari, S.; Verma, A.; Rahangdale, S.; Shah Hassan, S.; et al. Conserved host-pathogen PPIs. Globally conserved inter-species bacterial PPIs based conserved host-pathogen interactome derived novel target in C. pseudotuberculosis, C. diphtheriae, M. tuberculosis, C. ulcerans, Y. pestis, and E. coli targeted by piper betel compounds. Integr. Biol. 2013, 5, 495-509.

15. Perumal, D.; Lim, C.S.; Sakharkar, K.R.; Sakharkar, M.K. Differential genome analyses of metabolic enzymes in Pseudomonas aeruginosa for drug target identification. In Silico Biol. 2007, 7, 453-465. [PubMed]

16. Pizza, M.; Scarlato, V.; Masignani, V.; Giuliani, M.M.; Arico, B.; Comanducci, M.; Jennings, G.T.; Baldi, L.; Bartolini, E.; Capecchi, B.; et al. Identification of vaccine candidates against serogroup B meningococcus by whole-genome sequencing. Science 2000, 287, 1816-1820. [CrossRef] [PubMed]

17. Asif, S.M.; Asad, A.; Faizan, A.; Anjali, M.S.; Arvind, A.; Neelesh, K.; Hirdesh, K.; Sanjay, K. Dataset of potential targets for Mycobacterium tuberculosis H37Rv through comparative genome analysis. Bioinformation 2009, 4, 245-248. [CrossRef] [PubMed] 
18. Dutta, A.; Singh, S.K.; Ghosh, P.; Mukherjee, R.; Mitter, S.; Bandyopadhyay, D. In silico identification of potential therapeutic targets in the human pathogen Helicobacter pylori. In Silico Biol 2006, 6, 43-47. [PubMed]

19. Chong, C.E.; Lim, B.S.; Nathan, S.; Mohamed, R. In silico analysis of Burkholderia pseudomallei genome sequence for potential drug targets. In Silico Biol 2006, 6, 341-346. [PubMed]

20. Sakharkar, K.R.; Sakharkar, M.K.; Chow, V.T. A novel genomics approach for the identification of drug targets in pathogens, with special reference to Pseudomonas aeruginosa. In Silico Biol 2004, 4, 355-360. [PubMed]

21. Rathi, B.; Sarangi, A.N.; Trivedi, N. Genome subtraction for novel target definition in Salmonella typhi. Bioinformation 2009, 4, 143-150. [CrossRef] [PubMed]

22. Barh, D.; Kumar, A. In silico identification of candidate drug and vaccine targets from various pathways in Neisseria gonorrhoeae. In Silico Biol 2009, 9, 225-231. [PubMed]

23. Barh, D.; Jain, N.; Tiwari, S.; Parida, B.P.; D'Afonseca, V.; Li, L.; Ali, A.; Santos, A.R.; Guimaraes, L.C.; de Castro Soares, S.; et al. A novel comparative genomics analysis for common drug and vaccine targets in Corynebacterium pseudotuberculosis and other CMN group of human pathogens. Chem. Biol. Drug Des. 2011, 78, 73-84. [CrossRef] [PubMed]

24. Aronov, A.M.; Verlinde, C.L.; Hol, W.G.; Gelb, M.H. Selective tight binding inhibitors of trypanosomal glyceraldehyde-3-phosphate dehydrogenase via structure-based drug design. J. Med. Chem. 1998, 41, 4790-4799. [CrossRef] [PubMed]

25. Singh, S.; Malik, B.K.; Sharma, D.K. Molecular modeling and docking analysis of entamoeba histolytica glyceraldehyde-3 phosphate dehydrogenase, a potential target enzyme for anti-protozoal drug development. Chem. Biol. Drug Des. 2008, 71, 554-562. [CrossRef] [PubMed]

26. Li, L. Orthomcl: Identification of ortholog groups for eukaryotic genomes. Genome Res. 2003, 13, $2178-2189$. [CrossRef] [PubMed]

27. Soares, S.C.; Geyik, H.; Ramos, R.T.; de Sa, P.H.; Barbosa, E.G.; Baumbach, J.; Figueiredo, H.C.; Miyoshi, A.; Tauch, A.; Silva, A.; et al. Gipsy: Genomic island prediction software. J. Biotechnol. 2016, 232, 2-11. [CrossRef] [PubMed]

28. Naz, A.; Awan, F.M.; Obaid, A.; Muhammad, S.A.; Paracha, R.Z.; Ahmad, J.; Ali, A. Identification of putative vaccine candidates against Helicobacter pylori exploiting exoproteome and secretome: A reverse vaccinology based approach. Infect. Genet. Evol. 2015, 32, 280-291. [CrossRef] [PubMed]

29. Barinov, A.; Loux, V.; Hammani, A.; Nicolas, P.; Langella, P.; Ehrlich, D.; Maguin, E.; van de Guchte, M. Prediction of surface exposed proteins in streptococcus pyogenes, with a potential application to other gram-positive bacteria. Proteomics 2009, 9, 61-73. [CrossRef] [PubMed]

30. He, Y.; Xiang, Z.; Mobley, H.L.T. Vaxign: The first web-based vaccine design program for reverse vaccinology and applications for vaccine development. J. Biomed. Biotechnol. 2010, 2010, 1-15. [CrossRef] [PubMed]

31. Capriles, P.V.S.Z.; Guimarães, A.C.R.; Otto, T.D.; Miranda, A.B.; Dardenne, L.E.; Degrave, W.M. Structural modelling and comparative analysis of homologous, analogous and specific proteins from Trypanosoma cruzi versus Homo sapiens: Putative drug targets for chagas' disease treatment. BMC Genomics 2010, 11, 610. [CrossRef] [PubMed]

32. Mondal, S.I.; Ferdous, S.; Jewel, N.A.; Akter, A.; Mahmud, Z.; Islam, M.M.; Afrin, T.; Karim, N. Identification of potential drug targets by subtractive genome analysis of Escherichia coli O157:H7: An in silico approach. Adv. Appl. Bioinform. Chem. 2015, 8, 49-63. [CrossRef] [PubMed]

33. Duffield, M.; Cooper, I.; McAlister, E.; Bayliss, M.; Ford, D.; Oyston, P. Predicting conserved essential genes in bacteria: In silico identification of putative drug targets. Mol. Biosyst. 2010, 6, 2482-2489. [CrossRef] [PubMed]

34. Delcour, A.H. Outer membrane permeability and antibiotic resistance. Biochim. Biophys. Acta 2009, 1794, 808-816. [CrossRef] [PubMed]

35. Vaara, M. Agents that increase the permeability of the outer membrane. Microbiol. Rev. 1992, 56, $395-411$. [PubMed]

36. Gasteiger, E.; Hoogland, C.; Gattiker, A.; Duvaud, S.E.; Wilkins, M.R.; Appel, R.D.; Bairoch, A. Protein identification and analysis tools on the expasy server. In The Proteomics Protocols Handbook; Walker, J.M., Ed.; Humana Press: New York, NY, USA, 2005; pp. 571-607.

37. Thomsen, R.; Christensen, M.H. Moldock: A new technique for high-accuracy molecular docking. J. Med. Chem. 2006, 49, 3315-3321. [CrossRef] [PubMed] 
38. Hwang, B.; Lee, J.; Liu, Q.H.; Woo, E.R.; Lee, D.G. Antifungal effect of (+)-pinoresinol isolated from Sambucus williamsii. Molecules 2010, 15, 3507-3516. [CrossRef] [PubMed]

39. Cespedes, C.L.; Avila, J.G.; Garcia, A.M.; Becerra, J.; Flores, C.; Aqueveque, P.; Bittner, M.; Hoeneisen, M.; Martinez, M.; Silva, M. Antifungal and antibacterial activities of Araucaria araucana (Mol.) K. Koch heartwood lignans. Z. Naturforsch. C 2006, 61, 35-43. [CrossRef] [PubMed]

40. Coordinators, N.R. Database resources of the national center for biotechnology information. Nucleic Acids Res. 2016, 44, 7-19.

41. Brettin, T.; Davis, J.J.; Disz, T.; Edwards, R.A.; Gerdes, S.; Olsen, G.J.; Olson, R.; Overbeek, R.; Parrello, B.; Pusch, G.D.; et al. Rasttk: A modular and extensible implementation of the RAST algorithm for building custom annotation pipelines and annotating batches of genomes. Sci. Rep. 2015, 5. [CrossRef] [PubMed]

42. Zhang, R.; Ou, H.Y.; Zhang, C.T. Deg: A database of essential genes. Nucleic Acids Res. 2004, 32, D271-D272. [CrossRef] [PubMed]

43. Petersen, T.N.; Brunak, S.; von Heijne, G.; Nielsen, H. Signalp 4.0: Discriminating signal peptides from transmembrane regions. Nat. Methods 2011, 8, 785-786. [CrossRef] [PubMed]

44. Sonnhammer, E.L.; von Heijne, G.; Krogh, A. A hidden markov model for predicting transmembrane helices in protein sequences. Proc. Int. Conf. Intell. Syst. Mol. Biol. 1998, 6, 175-182. [PubMed]

45. Mitchell, A.; Chang, H.Y.; Daugherty, L.; Fraser, M.; Hunter, S.; Lopez, R.; McAnulla, C.; McMenamin, C.; Nuka, G.; Pesseat, S.; et al. The interpro protein families database: The classification resource after 15 years. Nucleic Acids Res. 2015, 43, D213-D221. [CrossRef] [PubMed]

46. Hassan, S.S.; Tiwari, S.; Guimaraes, L.C.; Jamal, S.B.; Folador, E.; Sharma, N.B.; de Castro Soares, S.; Almeida, S.; Ali, A.; Islam, A.; et al. Proteome scale comparative modeling for conserved drug and vaccine targets identification in Corynebacterium pseudotuberculosis. BMC Genom. 2014, 15. [CrossRef]

47. Gutmanas, A.; Alhroub, Y.; Battle, G.M.; Berrisford, J.M.; Bochet, E.; Conroy, M.J.; Dana, J.M.; Fernandez Montecelo, M.A.; van Ginkel, G.; Gore, S.P.; et al. PDBE: Protein data bank in Europe. Nucleic Acids Res. 2014, 42, D285-D291. [CrossRef] [PubMed]

48. Tiwari, S.; da Costa, M.P.; Almeida, S.; Hassan, S.S.; Jamal, S.B.; Oliveira, A.; Folador, E.L.; Rocha, F.; de Abreu, V.A.; Dorella, F.; et al. C. pseudotuberculosis PhoP confers virulence and may be targeted by natural compounds. Integr. Biol. 2014, 6, 1088-1099. [CrossRef] [PubMed]

49. Pettersen, E.F.; Goddard, T.D.; Huang, C.C.; Couch, G.S.; Greenblatt, D.M.; Meng, E.C.; Ferrin, T.E. Ucsf chimera-A visualization system for exploratory research and analysis. J. Comput. Chem. 2004, 25, 1605-1612. [CrossRef] [PubMed]

50. Kanehisa, M.; Goto, S. Kegg: Kyoto encyclopedia of genes and genomes. Nucleic Acids Res. 2000, $28,27-30$. [CrossRef] [PubMed]

(C) 2017 by the authors; licensee MDPI, Basel, Switzerland. This article is an open access article distributed under the terms and conditions of the Creative Commons Attribution (CC BY) license (http:/ / creativecommons.org/licenses/by/4.0/). 